\title{
Pengaruh Sikap dan Persepsi Kontrol Perilaku Terhadap Niat Whistleblowing Internal-Eksternal dengan Persepsi Dukungan Organisasi Sebagai Variabel Pemoderasi
}

Ilham Maulana Saud *

Prodi Akuntansi Universitas Muhammadiyah Yogyakarta, Jln. Lingkar Selatan, Kasihan, Bantul, D. I. Yogyakarta

\author{
A R T I C LE IN F O \\ Article history: \\ received 19 Mar 2016 \\ revised 23 Jun 2016 \\ accepted 30 Jun 2016

\section{Keywords:} \\ Perceived Behavior \\ Control; Perceived \\ Organizational Support; \\ Whistleblowing \\ Intention
}

\begin{abstract}
A B S T RA C T
This study aims to examine the influence of attitude and perceived behavior control empirically toward the whistleblowing intention of the internal-external with the perceived organizational support as the moderating variables. This study using survey method with 127 respondents of the permanent staffs of Universitas Muhammadiyah Yogyakarta (UMY) and employs hierarchical regression analysis. The results reveal the attitude has significant influence toward internal whistleblowing intention and the perceived of organizational supporting has significant influence as moderating variable which strengthen the influence of the perceived behavior control toward the internal-external whistleblowing intention.
\end{abstract}

(C) 2016 JAI. All rights reserved

\section{PENDAHULUAN}

Kebijakan whistleblowing kembali menjadi tranding topic setelah terungkapnya kasus perusahaan Enron, WorldCom, Anderson, dan Tyco yang mendorong regulator pasar modal Amerika Serikat mengeluarkan regulasi, yaitu Sarbanes Oxley Act of 2002 (SOX). Salah satu seruan SOX adalah perusahaan publik diwajibkan untuk mengembangkan sistem whistleblowing yang merupakan bagian dari sistem pengendalian internal (Brennan dan Kelly, 2007).

Sama halnya di Indonesia, regulasi mengenai whistleblowing telah diatur dalam Undang-Undang Nomor 13 Tahun 2006 tentang Perlindungan Saksi dan Korban serta Surat Edaran Mahkamah Agung Nomor 4 Tahun 2011 tentang Perlakuan terhadap Pelapor Tindak Pidana (whistleblower) dan Saksi Pelaku yang Bekerja Sama. Dengan adanya aturan tersebut, maka sistem whistleblowing sangat penting bagi organisasi, sehingga diperlukan sistem whistleblowing yang efektif yang diharapkan dapat meningkatkan partisipasi karyawan dalam melaporkan kecurangan.

Hal terpenting dalam penerapan sistem whistleblowing adalah apakah karyawan yang mengetahui terjadinya kecurangan mau melaporkan (whistleblower) atau tidak. Rothschild dan Miethe (1999) menyatakan bahwa sebagian besar whistleblower dinilai tidak loyal terhadap organisasi, dan mereka mungkin akan mendapat penolakan dari karyawan lainnya dalam organisasi (Elliston, 1982). Kondisi tersebut menjadi dilema etis bagi whistleblower ketika berasal dari internal organisasi, sehingga penting bagi whistleblower memperoleh dukungan dan perlindungan dari organisasi.

Alleyne et al. (2013) menjelaskan pentingnya persepsi dukungan organisasi bagi individu untuk melaporkan tindakan tidak etis. Hal ini didasarkan pada teori pertukaran sosial, organisasi yang memperlakukan karyawan dengan baik menimbulkan rasa kewajiban dalam diri karyawan, sehingga untuk memenuhi perasaan kewajibannya, karyawan merespon dengan cara yang mengungtungkan organisasi.

Persepsi dukungan organisasi mengacu pada keyakinan luas yang dimiliki karyawan mengenai sejauh mana organisasi menghargai kontribusi dan peduli terhadap kesejahteraan karyawannya (Eisenberger et al., 1986). Dengan demikian, persepsi dukungan organisasi yang tinggi menghasilkan dampak positif terhadap sikap dan perilaku karyawan untuk suatu kebaikan yang bermanfaat bagi organisasi, misalnya melaporkan kecurangan yang terjadi dalam organisasi. Meningkatnya partisipasi karyawan untuk melaporkan tindakan-tindakan kecurangan dapat meningkatkan keefektifan sistem pengendalian internal organisasi (Patel, 2003). Hasil penelitian Adebayo (2005) mengenai sikap etis dan perilaku prososial di kepolisian Nigeria menemukan bahwa persepsi dukungan organisasi yang dirasakan 
memoderasi hubungan antara sikap dan perilaku prososial. Hooks et al. (1994), Kaplan dan Whitecotton (2001) menunjukkan adanya hubungan antara tingkat persepsi dukungan organisasi dengan akses untuk mengungkapkan kecurangan.

Penelitian sebelumnya yang dilakukan Park dan Blenkinsopp (2009) dan Winardi (2013) telah menemukan beberapa faktor individu yang mempengaruhi niat whistleblowing dengan menggunakan teori perilaku terencana yang dikembangkan oleh Ajzen (1991). Hasil penelitian Winardi (2013) menemukan bahwa sikap dan persepsi kontrol perilaku berpengaruh positif terhadap niat whistleblowing internal. Park dan Blenkinsopp (2009) juga menemukan bahwa sikap dan kontrol perilaku berpengaruh positif terhadap niat whistleblowing internal, tetapi tidak berpengaruhi positif terhadap niat whistleblowing eksternal.

Tujuan penelitian ini adalah untuk menguji apakah sikap dan persepsi kontrol perilaku berpengaruh positif terhadap niat whistleblowing internaleksternal dan apakah persepsi dukungan organisasi memoderasi hubungan pengaruh sikap dan kontrol perilaku terhadap niat whistle-blowing internalekstenal. Penelitian ini penting karena, pertama, beberapa penelitian sebelumnya belum menggunakan variabel persepsi dukungan organisasi. Kedua, pada penelitian sebelumnya oleh Winardi (2013) hanya menggunakan jalur whistleblowing internal untuk menggungkap kecurangan, sedangkan penelitian ini menggunakan konteks niat whistleblowing internal-eksternal. Ketiga, dengan menggunakan responden yang berbeda, penelitian ini ingin mengkonfirmasi dan menindaklanjuti hasil penelitian yang dilakukan oleh Park dan Blenkinsopp (2009) yang juga menggunakan jalur pelaporan internal-eksternal.

Kontribusi teoritis penelitian ini adalah memberikan penjelasan bahwa sikap individu berpengaruh positif terhadap niat whistleblowing internal. Selain itu, persepsi dukungan organisasi menjadi aspek yang dapat memperkuat pengaruh persepsi kontrol perilaku terhadap niat whistleblowing internal-eksternal. Secara praktik, penelitian ini memberikan informasi bagi organisasi bahwa pentingnya dukungan organisasi bagi karyawan untuk mengungkapkan kecurangan.

\section{TINJAUAN LITERATUR DAN PERUMUSAN HIPOTESIS}

\section{Teori Perilaku Direncanakan}

Ajzen (1991) mendefinisikan bahwa intensi merupakan pencerminan dari tiga faktor utama yaitu sikap terhadap perilaku, norma subjektif, dan persepsi kontrol perilaku. Sikap merupakan suatu disposisi untuk merespon secara positif atau negatif perilaku tertentu. Sikap terhadap perilaku ditentukan oleh kombinasi antara keyakinan perilaku dan evaluasi hasil. Keyakinan perilaku adalah keyakinan individu mengenai konsekuensi positif atau negatif dari perilaku tertentu, sedangkan evaluasi hasil merupakan evaluasi individu terhadap konsekuensi yang didapatkan dari suatu perilaku (Ajzen, 1991).

Sikap merupakan suatu disposisi untuk merespon secara positif atau negatif perilaku tertentu. Sikap terhadap perilaku ditentukan oleh kombinasi antara keyakinan perilaku dan evaluasi hasil. Keyakinan perilaku adalah keyakinan individu mengenai konsekuensi positif atau negatif dari perilaku tertentu, sedangkan evaluasi hasil merupakan evaluasi individu terhadap konsekuensi yang didapatkan dari suatu perilaku (Ajzen, 1991). Hal ini menunjukkan bahwa individu yang percaya bahwa suatu perilaku dapat memberikan hasil yang positif maka individu tersebut memiliki sikap positif terhadap perilaku tersebut dan sebaliknya, jika individu meyakini bahwa suatu perilaku dapat memberikan hasil yang negatif maka individu tersebut memiliki sikap negatif terhadap perilaku tersebut.

Persepsi kontrol perilaku sebagai fungsi yang didasarkan oleh keyakinan yang disebut sebagai keyakinan kontrol, yaitu keyakinan individu mengenai ada atau tidak adanya faktor yang mendukung atau menghambat individu untuk melakukan suatu perilaku. Keyakinan ini didasarkan pada pengalaman masa lalu serta informasi dari pengalaman orang lain (Ajzen, 1991). Ajzen (1991) menjelaskan bahwa semakin individu merasakan banyak faktor pendukung dan sedikit faktor penghambat untuk dapat melakukan suatu perilaku, maka lebih besar kontrol yang mereka rasakan atas perilaku tersebut dan sebaliknya, jika semakin sedikit individu merasakan faktor pendukung dan banyak faktor penghambat untuk dapat melakukan suatu perilaku, maka individu cenderung mempersepsikan diri sulit untuk melakukan perilaku tersebut.

\section{Teori Pertukaran Sosial}

Cropanzano dan Mictchell (2005) menjelaskan bahwa dasar teori pertukaran sosial adalah hubungan yang meningkat dari waktu ke waktu menjadi hubungan yang saling mempercayai, loyal, dan saling berkomitmen selama kedua belah pihak menaati aturan-aturan pertukaran. Peraturan mengenai pertukaran umumnya melibatkan hubungan timbal balik atau aturan membayar kembali dalam bentuk tindakan dari suatu pihak sebagai respon dari tindakan pihak lain (Cropanzano dan Mictchell, 
2005). Pedekatan pertukaran sosial mengintegrasikan keyakinan karyawan tentang bagaimana mereka diperlakukan oleh organisasinya dan bagaimana organisasi berkomitmen kepada mereka (Eisenberger et al., 1986). Dengan demikian, jika karyawan percaya bahwa organisasi berkomitmen kepadanya maka karyawan juga akan berkomitmen kepada organisasi.

\section{Whistleblowing}

Miceli dan Near (1985) mendefinisikan whistleblowing adalah suatu pengungkapan oleh anggota organisasi tentang praktik ilegal, tidak bermoral atau tidak sah di bawah kendali atasan mereka kepada orang-orang atau organisasi yang dapat mempengaruhi tindakan. Whistleblowing juga dapat didefinisikan sebagai upaya anggota saat ini atau masa lalu dari suatu organisasi untuk memberikan peringatan kepada top management organisasi atau kepada publik mengenai sebuah kesalahan serius yang dibuat atau disembunyikan oleh organisasi (Ahern dan McDonald, 2002; Putri, 2016).

Individu yang melakukan whistleblowing disebut whistleblower, Miceli dan Near (1985) menjelaskan bahwa yang dapat disebut sebagai whistleblower memiliki empat karakteristik, yaitu (1) karyawan atau mantan karyawan organisasi yang organisasinya mengalami kecurangan; (2) tidak memiliki otorisasi untuk mengubah atau menghentikan kecurangan yang berada di bawah kendalinya; (3) diizinkan atau tidak diizinkan membuat laporan; (4) tidak menduduki posisi yang tugasnya mensyaratkan untuk melakukan pelaporan kecurangan korporat.

Whistleblowing dapat terjadi melalui jalur internal maupun eksternal. Whistleblowing internal terjadi ketika seorang karyawan mengetahui kecurangan yang dilakukan karyawan lainnya kemudian melaporkan kecurangan tersebut kepada atasannya. Sedangkan, whistleblowing eksternal terjadi ketika seorang karyawan mengetahui kecurangan yang dilakukan organisasi atau anggota dalam organisasi, kemudian memberitahukannya kepada pihak di luar organisasi atau penegak hukum karena kecurangan tersebut merugikan masyarakat (Elias, 2008).

Park dan Blenkinsopp (2009) menjelaskan bahwa jalur pelaporan whistleblowing tidak hanya sebatas internal dan eksternal, tetapi terdiri dari tiga dimensi, yaitu formal dan informal, anonim dan teridentifikasi, internal dan eksternal, setiap dimensi tersebut merupakan pilihan bagi karyawan. Kaplan (2012) menemukan bahwa whistleblower berperilaku berbeda dalam membuat pilihan jalur pelaporan yang sesuai untuk mereka. Secara khusus, hasil penelitiannya menunjukkan bahwa pelaporan niat peserta dalam hal jalur anonim atau teridentifikasi berpengaruh ketika adanya pertimbangan tindakan pembalasan.

\section{Sikap dan Niat Whistleblowing}

Sikap terhadap whistleblowing menurut Park dan Blenkinsopp (2009) mengenai sejauh mana individu memiliki evaluasi menguntungkan atau tidak menguntungan dari whistleblowing adalah jumlah keyakinan yang dimiliki karyawan tentang konsekuensi dari whistleblowing dan evaluasi subjektif terhadap konsekuensi tersebut. Dengan demikian, seseorang untuk dapat menjadi whistleblower harus memiliki kompenen keyakinan bahwa whistleblowing adalah tindakan yang memiliki konsekuensi positif misalnya pencegahan yang dapat merugikan organisasi, kontrol terhadap tindakan korupsi, peningkatan kepentingan umum, kepuasan moral dan tugas karyawan (Callahan dan Dworkin, 2000). Selanjutnya keyakinan terhadap konsekuensi positif tersebut dievaluasi oleh sistem nilai individu seseorang dan menghasilkan sikap, sikap positif yang mampu mendorong kecenderungan seseorang untuk melakukan whistleblowing. Sehingga, semakin besar kecenderungan sikap positif seseorang untuk melakukan whistleblowing semakin besar kemungkinan niat seseorang untuk melakukan whistleblowing:

Sejalan dengan konsep yang dikemukakan di atas, secara empiris beberapa penelitian telah membuktikan konsep sikap memiliki hubungan positif terhadap niat whistleblowing. Park dan Blenkinsopp (2009) menemukan bahwa sikap petugas kepolisian terhadap whistleblowing memiliki efek positif signifikan terhadap niat whistleblowing. Trongmateerut dan Sweeney (2013) yang membanding budaya Amerika Serikat dan Thailand juga menjelaskan bahwa niat whistleblowing dipengaruhi oleh sikap. Winardi (2013) juga menemukan bahwa sikap berpengaruh positif terhadap niat whistleblowing internal. Hal ini menunjukkan bahwa sikap positif seseorang terhadap tindakan kecurangan semakin besar kemungkinan seseorang untuk melakukan whistleblowing: Berdasarkan penjelasan di atas, maka hipotesis pertama penelitian ini adalah:

$\mathrm{H}_{1}$ : Sikap terhadap whistleblowing berpengaruh positif terhadap niat whistleblowing internaleksternal.

\section{Persepsi Kontrol Perilaku dan Niat Whistleblowing}

Persepsi Kontrol perilaku yang dirasakan dalam whistleblowing dapat diperkirakan dengan cara faktor kontrol dan evaluasi hasil (Park dan Blenkinsopp, 2009). Salah satu faktor kontrol dari 
whistleblowing berasal dari keyakinan tentang hambatan organisasi, yaitu menggagalkan atau dengan sengaja mengabaikan laporan tersebut. Terkait dengan keyakinan negatif individu, seperti kekhawatiran individu tentang pembalasan karena pelaporan yang dilakukan, faktor ini merupakan salah satu faktor paling penting yang dapat mencengah karyawan untuk melaporkan perbuatan tidak sah atau etis (Miceli dan Near, 1992; Mesmer-Magnus dan Viswesvaran, 2005). Sehingga sangat penting bagi karyawan yang berniat untuk melakukan whistleblowing dilindungi dari pembalasan (Gorta dan Fornell, 1995).

Penelitian sebelumnya oleh Winardi (2013) menemukan bahwa persepsi kontrol perilaku berpengaruh positif terhdap niat whistleblowing internal. Park dan Blenkinsop (2009) menemukan bahwa persepsi kontrol perilaku yang dirasakan memiliki pengaruh positif signifikan pada niat whistleblowing internal. Teori ini memprediksi bahwa semakin besar kontrol perilaku yang dirasakan, maka semakin kuat niat seseorang untuk melakukan perilaku tersebut (Ajzen, 1991). Dengan demikian, seseorang yang meyakini bahwa ia memiliki kesempatan besar dan tidak menghadapi hambatan besar untuk melaporkan tindakan kecurangan, maka semakin kuat persepsi individu terhadap kontrol untuk melaporkan tindakan kecurangan tersebut. Berdasarkan dari penjelasan di atas, maka hipotesis kedua penelitian ini adalah:

$\mathrm{H}_{2}$ : Persepsi kontrol perilaku yang dirasakan berpengaruh positif terhadap niat whistleblowing internal-eksternal.

\section{Persepsi Dukungan Organisasi dan Niat Whistleblowing}

Mengadopsi kerangka teori pertukaran sosial, Eisenberger et al. (1986) berpendapat bahwa keyakinan tersebut mendasari kesimpulan karyawan mengenai komitmen organisasi mereka terhadap persepsi dukungan organisasi yang dirasakan, sehingga berkontribusi terhadap komitmen karyawan untuk organisasi. Karyawan merasa nyaman atas pengambilan keputusannya yang terkait dengan pelaporan tindakan tidak etis ketika organisasi mendukung tindakan karyawan (Alleyne et al., 2013).

Wayne et al. (1997) menjelaskan bahwa besarnya persepsi dukungan organisasi yang dirasakan oleh karyawan menciptakan perasaan kewajiban, karyawan tidak hanya merasa bahwa mereka harus berkomitmen untuk atasan mereka, tetapi juga merasakan suatu kewajiban dengan terlibat dalam perilaku yang mendukung tujuan organisasi. Alleyne et al. (2013) menyatakan bahwa persepsi dukungan organisasi yang dirasakan merupakan salah satu faktor yang mendukung seorang individu untuk melaporkan tindakan tidak etis dalam organisasinya. Individu harus menilai tingkat dukungan yang diharapkan ketika akan memutuskan untuk melaporkan kesalahan apapun, mengingat berbagai dampak negatif yang timbul jika kurangnya dukungan dari organisasi.

Sejalan dengan teori pertukaran sosial dan norma timbal balik, persepsi dukungan organisasi menciptakan perasaan balas budi karyawan terhadap organisasi dan dapat dikurangi dengan usaha yang timbal balik (Gouldner, 1960). Hal ini menunjukkan bahwa persepsi dukungan organisasi yang tinggi menghasilkan dampak positif terhadap sikap dan perilaku karyawan untuk suatu kebaikan yang bermanfaat bagi organisasi, misalnya melaporkan kecurangan yang terjadi dalam organisasi. Dengan demikian, dukungan organisasi yang dirasakan diharapkan dapat memperkuat hubungan faktor sikap dan persepsi kontrol perilaku terhadap niat seseorang untuk melaporkan tindakan kecurangan. Berdasarkan penjelasan di atas, maka hipotesis ketiga penelitian ini adalah:

$\mathrm{H}_{3}$ : Persepsi dukungan organisasi yang dirasakan memoderasi hubungan sikap dan persepsi kontrol perilaku terhadap niat whistleblowing internal-eksternal.

\section{METODE PENELITIAN}

\section{Desain Penelitian dan Pemilihan Sampel}

Penelitian ini menggunakan metode survei dalam bentuk kuesioner. Sampel yang digunakan adalah karyawan tetap (tenaga kependidikan) Universitas Muhammadiyah Yogyakarta dengan masa kerja lebih dari dua tahun dengan teknik pemilihan sampel menggunakan non probability sampling yaitu convenience sampling. Penentuan ukuran jumlah sampel penelitian ini mengacu ketentuan Isaac dan Michael yang berdasarkan tingkat kesalahan (Sugiyono, 2013). Tingkat kesalahan yang digunakan adalah $5 \%$.

\section{Definisi Operasional Variabel dan Pengukurannya Sikap}

Sikap adalah derajat individu untuk mengevaluasi dan menilai sesuatu yang menguntungkan atau tidak menguntungkan (Ajzen, 1991). Untuk mengukur sikap dalam penelitian ini menggunakan 


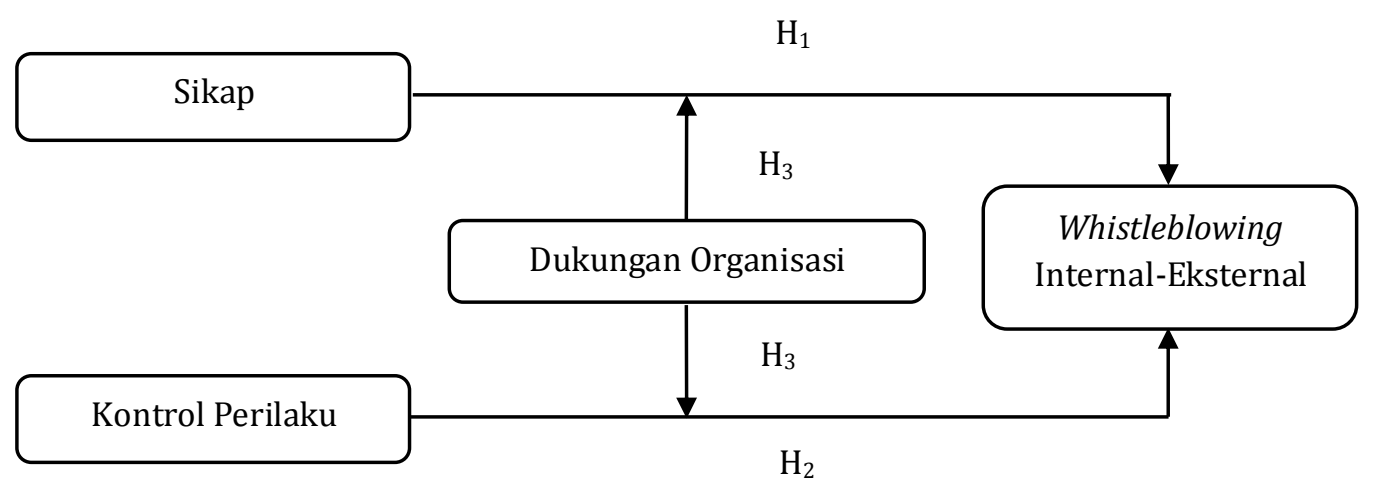

\section{Gambar 1. Kerangka Konseptual Penelitian}

model Park dan Blenkinsopp (2009) yang diadopsi oleh Winardi (2013). Responden diminta menjawab dua pertanyaan, yaitu pertanyaan untuk menilai kepercayaan terhadap perilaku (behavioral belief) dengan menggunakan 5 skala Likert dari sangat tidak setuju hingga sangat setuju dan pertanyaan untuk mengevaluasi seberapa penting jika melakukan perilaku tersebut (evaluation of important) dengan menggunakan 5 skala Likert dari sangat tidak penting hingga sangat penting.

\section{Persepsi Kontrol Perilaku}

Persepsi kontrol perilaku adalah persepsi individu tentang tingkat kesulitan dalam melakukan perilaku tertentu (Ajzen, 1991). Untuk mengukur kontrol perilaku dalam penelitian ini menggunakan model Park dan Blenkinsopp (2009) yang diadopsi Winardi (2013). Responden diminta menjawab dua pertanyaan, yaitu pertanyaan untuk menilai keyakinan mengenai kemampuan dalam mengendalikan (control belief) dengan menggunakan 5 skala Likert dari sangat tidak setuju hingga sangat setuju dan pertanyaan untuk menilai persepsi tentang kekuatan jika melakukan perilaku (perceived power) dengan menggunakan 5 skala Likert dari tidak berpengaruh hingga sangat berpengaruh.

\section{Persepsi Dukungan Organisasi}

Persepsi dukungan organisasi adalah keyakinan karyawan mengenai penghargaan, dukungan, dan perhatian yang diberikan organisasi atas kontribusi yang telah diberikan karyawan serta kepedulian organisasi terhadap kesejahteraan karyawan (Eisenberger et al., 1986). Persepsi dukungan organisasi dalam penelitian ini merupakan variabel moderasi yang diukur dengan menggunakan model Eisenberger et al. (1986). Responden diminta untuk menilai persepsi dukungan organisasi yang diterima oleh karyawan dengan 5 skala Likert dari sangat setuju hingga sangat setuju.

\section{Niat Whistleblowing}

Niat whistleblowing adalah suatu tindakan yang mungkin dilakukan individu untuk melaporkan suatu kesalahan atau perbuatan yang tidak etis (Miceli dan Near, 1985). Niat whistleblowing dalam penelitian ini merupakan variabel dependen yang diukur dengan menggunakan model Park dan Blenkinsopp (2009) yang diadopsi Winardi (2013). Responden diminta untuk menilai dua bentuk kasus korupsi yang diberikan yaitu serius dan kurang serius, dengan menggunakan jalur pelaporan anonim dan terindentifikasi, apakah responden melaporkan kasus tersebut ke pihak internal organisasi dan ke pihak eksternal di luar organisasi dengan menggunakan 5 skala Likert dari sangat rendah hingga sangat tinggi.

\section{Analisis Bias Metoda Umum}

Analisis bias metoda umum dilakukan karena penelitian ini menggunakan sumber yang sama untuk menjawab variabel independen maupun dependen sehingga dapat menimbulkan self report bias dan menyebabkan kesalahan pengukuran. Self report bias dalam penelitian ini dikontrol dengan menjamin anonimitas responden dan dijelaskan bahwa tidak ada jawaban yang benar ataupun salah (Hartono dan Abdillah, 2008).

Untuk mengontrol bias keinginan sosial, penelitian ini menggunakan pertanyaan-pertanyaan dengan third-person wording dalam keusioner agar bias keinginan sosial dapat diminimalkan, serta menggunakan beberapa item pertanyaan dikodekan terbalik (reverse-coded items) dengan tujuan untuk mengontrol bias motif konsistensi terhadap item pertanyaan (Hartono dan Abdillah, 2008). 


\section{HASIL DAN PEMBAHASAN}

\section{Responden Penelitian}

Kuesioner yang terkumpul sebanyak 133 dari 149 kuesioner yang dibagikan, sehingga tingkat respon sebesar 89\%. Dari 133 yang kembali hanya 127 kuesioner yang dapat digunakan untuk keperluan penelitian dengan karakteristik demografis responden ditunjukkan pada Tabel 1 .

Tabel 1. Karakteristik Demografis Responden

\begin{tabular}{llcc}
\hline & & $\begin{array}{c}\text { Jumlah } \\
\text { (Orang) }\end{array}$ & $\begin{array}{c}\text { Persentase } \\
\text { (\%) }\end{array}$ \\
\hline Jenis Kelamin & Laki-laki & 97 & 76 \\
& Perempuan & 30 & 24 \\
Umur & $29-30$ & 127 & 100 \\
& $31-40$ & 4 & 3 \\
& $41-50$ & 35 & 28 \\
& $>50$ & 25 & 50 \\
Lama Kerja & $4-10$ & 127 & 20 \\
& $11-20$ & 23 & 100 \\
& $21-30$ & 63 & 50 \\
& $>30$ & 38 & 30 \\
Jumlah & & 3 & 2 \\
\hline
\end{tabular}

\section{Uji Non-Response Bias}

Uji non-response bias bertujuan untuk melihat perbedaan jawaban responden berdasarkan waktu pengembalian kuesioner. Non-response bias perlu diuji untuk melihat apakah respon yang terlambat dari responden memberikan hasil yang bias dibandingkan respon yang tepat waktu, atau dapat juga respon yang terlambat bias karena responden mengisi kuesioner sekenanya karena sudah terlambat (Hartono dan Abdillah, 2008; Sofyani dan Akbar, 2013; 2015). Terdapat 107 kuesioner yang diterima pada awal waktu pengembalian dan 20 kuesioner yang diterima pada akhir waktu pengembalian. Nilai sig pada levene's test $>0,05$ yang artinya tidak ada perbedaan signifikan jawaban antara kedua kelompok tersebut. Secara keseluruhan, hasil menunjukkan bahwa tidak terjadi non-response bias dalam penelitian ini (lihat Tabel 2).

\section{Pengujian Validitas}

Berdasarkan hasil uji validitas yang ditampilkan pada Tabel 3, 4 dan 5, nilai factor loading untuk setiap item memiliki nilai $>0,5$. Hal ini menunjukkan bahwa item pertanyaan belief factors dan evaluation factors untuk variabel sikap dan persepsi kontrol perilaku, serta item pertanyaan variabel persepsi dukungan organisasi adalah valid, sehingga dapat digunakan untuk analisis selanjutnya (Hair et al., 2010; Evanauli dan Nazaruddin, 2013).

\section{Pengujian Reliabilitas}

Berdasarkan hasil uji reliabilitas yang ditampilkan pada Tabel 6, nilai cronbach alpha variabel sikap, persepsi kontrol perilaku, dan persepsi dukungan organisasi $>0,60$. Hal ini menunjukkan bahwa item-item pertanyaan semua variabel tersebut reliabel, sehingga dapat digunakan untuk analisis selanjutnya (Hair et al., 2010).

\section{Hasil Pengujian Hipotesis}

Pengujian hipotesis pada penelitian ini menggunakan Hierarchical Regression Analysis Berdasarkan hasil uji hipotesis pada tabel 7 menunjukkan bahwa sikap berpengaruh positif signifikan terhadap niat whistleblowing internal. Hasil ini mengkonfirmasi teori perilaku terencana, jika seseorang memiliki keyakinan bahwa memutuskan menjadi whistleblower memberikan konsekuensi positif dan meyakini pentingnya konsekuensi tersebut, maka seseorang akan memiliki kecenderungan sikap yang positif untuk mendukung tindakan whistleblowing, dengan demikian kondisi tersebut dapat meningkatkan niat seseorang untuk melakukan whistleblowing. Temuan ini sesuai dengan hasil beberapa penelitian sebelumnya, yaitu Park dan Blenkinsopp (2009) menemukan bahwa

Tabel 2. Hasil Uji Non-response Bias

\begin{tabular}{lcccc}
\hline \multicolumn{1}{c}{ Konstruk } & $\begin{array}{c}\text { Tepat } \\
\text { Waktu }\end{array}$ & $\begin{array}{c}\text { Terlambat } \mathbf{( N =} \\
\mathbf{2 0 )}\end{array}$ & \multicolumn{2}{c}{ Levene's Test for Equality of } \\
Variances \\
Sig.
\end{tabular}


Tabel 3. Hasil Uji Validitas Belief Factors

\begin{tabular}{llcc}
\hline \multicolumn{1}{c}{ Item } & Sikap & $\begin{array}{c}\text { Rotasi Factor Loading } \\
\text { Persepsi Kontrol Perilaku }\end{array}$ \\
\hline 1. & Sikap 1 &,- 077 &, 697 \\
2. & Sikap 2 &,- 074 &, 639 \\
3. & Sikap 3 &,- 054 &, 786 \\
4. & Sikap 4 &,- 150 &, 599 \\
5. & Sikap 5 &,- 141 &, 693 \\
6. & Persepsi Kontrol Perilaku 1 &, 600 &,- 273 \\
7. & Persepsi Kontrol Perilaku 2 &, 721 & -147 \\
8. & Persepsi Kontrol Perilaku 3 &, 722 &,- 235 \\
9. Persepsi Kontrol Perilaku 4 &, 701 &, 087 \\
10. Persepsi Kontrol Perilaku 5 &, 845 &,- 057 \\
\hline \multicolumn{2}{l}{ Persentase Varian } & 26,632 & 51,765 \\
& KMO &, 765 & \\
& Sig. &, 000 & \\
\hline
\end{tabular}

Tabel 4. Hasil Uji Validitas Evaluation Factors

\begin{tabular}{llcc}
\hline \multicolumn{1}{c}{ Item } & Sikap & $\begin{array}{c}\text { Rotasi Factor Loading } \\
\text { Persepsi Kontrol Perilaku }\end{array}$ \\
\hline 1. & Sikap 6 &, 695 &,- 097 \\
2. & Sikap 7 &, 815 &, 015 \\
3. & Sikap 8 &, 752 &,- 061 \\
4. & Sikap 9 &, 772 &, 072 \\
5. & Sikap 10 &, 803 &,- 043 \\
6. & Persepsi Kontrol Perilaku 6 &, 150 &, 769 \\
7. Persepsi Kontrol Perilaku 7 &,- 015 &, 797 \\
8. & Persepsi Kontrol Perilaku 8 &, 065 &, 641 \\
9. Persepsi Kontrol Perilaku 9 &,- 220 &, 691 \\
10. Persepsi Kontrol Perilaku 10 &,- 137 &, 755 \\
\hline \multicolumn{2}{l}{ Persentase Varian } & 30,475 & 57,523 \\
KMO &, 731 & \\
Sig. &, 000 & \\
\hline
\end{tabular}

Tabel 5. Hasil Uji Validitas Persepsi Dukungan Organisasi

\begin{tabular}{llc}
\hline \multicolumn{1}{c}{ Item } & Rotasi Factor Loading \\
\hline 1. & Persepsi Dukugan Organisasi 1 &, 705 \\
2. & Persepsi Dukugan Organisasi 2 &, 806 \\
3. & Persepsi Dukugan Organisasi 3 &, 601 \\
4. & Persepsi Dukugan Organisasi 4 &, 559 \\
5. & Persepsi Dukugan Organisasi 5 &, 780 \\
\hline \multicolumn{2}{l}{ Persentase Varian } & 48,558 \\
KMO &, 706 \\
Sig. &, 000 \\
\hline
\end{tabular}

Tabel 6. Hasil Uji Reliabilitas

\begin{tabular}{lc}
\hline Item & Cronbach Alpha \\
\hline Sikap: &, 704 \\
$\quad$ Behavioral Beliefs &, 820 \\
$\quad$ Evaluation of Importance & \\
Persepsi Kontrol Perilaku: &, 779 \\
$\quad$ Control Beliefs &, 782 \\
$\quad$ Perceived Power &, 724 \\
Persepsi Dukungan Organisasi & \\
\hline
\end{tabular}

sikap petugas kepolisian memiliki efek positif signifikan terhadap niat whistleblowing internal. Trongmateerut dan Sweeney (2013) yang memban- ding budaya Amerika Serikat dan Thailand juga menjelaskan bahwa niat whistleblowing dipengaruhi oleh sikap.

Tidak terdukungnya pengaruh sikap terhadap niat whistleblowing eksternal menunjukkan bahwa responden yang memiliki sikap positif terhadap tindakan kecurangan lebih cenderung memilih jalur internal untuk melaporkan tindakan kecurangan. Hasil ini konsisten dengan penelitian Park dan Blenkinsopp (2009) yang menemukan bahwa sikap tidak berpengaruh terhadap niat whistleblowing eksternal. 
Tabel 7. Hasil Uji Hipotesis

\begin{tabular}{lcccc} 
& \multicolumn{2}{c}{ WB-Internal } & \multicolumn{2}{c}{ WB-Eksternal } \\
& Model 1 & Model 2 & Model 3 & Model 4 \\
\hline Konstanta &, 075 &, 658 &, 141 &, 560 \\
Sikap &, $002^{*}$ &, 001 &, 324 &, 236 \\
Persepsi Kontrol Perilaku &, 455 &, 813 &, 657 &, 768 \\
Persepsi Dukunagan Organisasi &, 898 &, 265 &, 819 &, 635 \\
SKP_PDO (Moderasi) & &, 293 &, 626 \\
KP_PDO (Moderasi) & &, $015^{*}$ &, $033^{*}$ \\
\hline $\boldsymbol{R}^{\prime}$ &, 159 &, 249 &, 047 &, $\mathbf{1 0 9}$ \\
$\boldsymbol{R}$ &, 399 &, 499 &, 218 &, 330 \\
F-value & 3,226 & 2,890 &, 846 & 1,061 \\
${ }^{*}$ p $<0,05$ & & & & \\
\hline
\end{tabular}

Hasil pengujian persepsi kontrol perilaku menunjukkan tidak adanya berpengaruh positif terhadap niat whistleblowing internal dan whistleblowing eksternal. Namun, untuk pengujian moderasi variabel persepsi dukungan organisasi dengan variabel persepsi kontrol perilaku terhadap niat whistleblowing internal dan eksternal menghasilkan bahwa persepsi dukungan organisasi merupakan variabel pemoderasi yang memperkuat pengaruh persepsi kontrol perilaku terhadap niat whistlebowing internal-eksternal. Temuan ini menunjukkan bahwa ketika seseorang meyakini bahwa tidak ada hambatan dan memiliki kesempatan besar untuk melaporkan tindakan kecurangan, maka semakin besar pula niat seseorang tersebut untuk melakukan tindakan whistleblowing, terlebih jika seseorang tersebut merasa bahwa organisasi mendukung dan memberikan perlindungan.

Hasil tersebut sesuai dengan teori pertukaran sosial dan norma timbal balik, ketika karyawan ingin melaporkan kecurangan dan karyawan meyakini bahwa mereka tidak akan mendapatkan ancaman atau sanksi baik secara ekonomi maupun sosial dari organisasi, maka akan menimbulkan dampak positif terhadap sikap dan perilaku karyawan dan meningkatkan niat karyawan untuk melakukan whistleblowing yang merupakan suatu tindakan yang bermanfaat bagi organisasi. Dengan demikian, penting bagi whistleblower untuk memastikan dukungan organisasi mengingat berbagai jenis ancaman yang mungkin diterima. Hasil ini sejalan dengan penelitian Adebayo (2005), Hooks et al. (1994), Kaplan dan Whitecotton (2001) yang menunjukkan adanya hubungan antara tingkat persepsi dukungan organisasi dengan akses untuk mengungkapkan kecurangan.

\section{SIMPULAN}

Berdasarkan hasil pengujian yang telah dilakukan dapat disumpulkan bahwa faktor individual, yaitu sikap dapat digunakan untuk menprediksi niat seseorang melakukan whistleblowing internal dan persepsi dukungan organisasi yang dirasakan terbukti sebagai sebagai variabel pemoderasi yang memperkuat pengaruh persepsi kontrol perilaku terhadap niat whistleblowing internal-eksternal.

Implikasi penelitian ini adalah sistem whistleblowing akan efektif jika seluruh elemen dalam organisasi dari tingkat terendah hingga top management organisasi mendukung dan melindungi karyawan yang ingin melaporkan tindakan kecurangan, mengingat berbagai ancaman atau pembalasan yang dapat diterima. Secara khusus, untuk menindaklanjuti salah satu rekomendasi hasil Mukatamar Muhammadiyah ke 47 poin kesembilan yaitu gerakan berjamaah melawan korupsi, penting bagi UMY atau lembaga-lembaga perserikatan Muhammadiyah untuk membuat dan menerapkan suatu kebijakan mengenai sistem whistleblowing dan secara umum bagi lembaga-lembaga pemerintah maupun swasta sebagai salah satu cara untuk meningkatkan sistem pengendalian internal, mengingat masih banyaknya kasus korupsi yang terungkap sampai saat ini.

Penelitian ini masih memiliki keterbatasan yang dapat diperbaiki pada penelitian selanjutnya. Pertama, responden dalam penelitian ini hanya terbatas pada tenaga kependidikan UMY yang memiliki budaya organisasi berbeda dengan perguruan tinggi atau instansi lainnya, sehingga generalisasi hasil penelitian ini harus dilakukan secara hati-hati. Oleh karena itu pada penelitian mendatang sebaiknya menambahkan responden dari perguruan tinggi lain, misalnya dari perguruan tinggi dari instansi pemerintahan atau swasta. Kedua, sampel organisasi atau perusahaan sebaiknya yang sudah menerapkan sistem whistleblowing secara penuh. Ketiga, rendahnya nilai koefisien determinasi $\left(R^{\prime}\right)$ menunjukkan masih banyak variabel-variabel lain diluar model penelitian ini dapat mempengaruhi niat untuk melakukan whistleblowing. 


\section{LAMPIRAN}

\section{Kasus 1}

Wawan terlibat dalam sebuah proyek untuk membuat anggaran pengadaan komputer yang akan digunakan untuk kantornya, yaitu Perguruan Tinggi ABC. Anto sebagai atasan Wawan meminta kepadanya untuk menaikkan nilai anggaran proyek pengadaan komputer (mark-up) dari Rp 5 milyar menjadi Rp 9 milyar. Wawan mengetahui bahwa mark-up lebih besar dari harga total komputer. Selain itu, Anto mengatakan bahwa lelang akan diatur supaya pemenangnya adalah perusahaan milik kerabat dekatnya. Wawan mengetahui yang dilakukan Anto melanggar hukum dan tidak etis. Namun saat mengingatkan Anto, Wawan mendapat ancaman penundaan kenaikan pangkatnya jika melaporkan mark-up dan peraturan pengadaan komputer tersebut. Seandainya Anda adalah Wawan.

(1) Bagaimana tingkat kemungkinan Anda akan melaporkan kasus tersebut kepada PIHAK INTERNAL di Perguruan Tinggi ABC (missalnya atasan Anda atau pihak manajemen yang lebih tinggi) TANPA memberitahukan identitas Anda?

(2) Bagaimana tingkat kemungkinan Anda akan melaporkan kasus tersebut kepada PIHAK EKSTERNAL di luar Perguruan Tinggi ABC (misalnya penegak hukum) TANPA memberitahukan identitas Anda?

(3) Bagaimanakah tingkat kemungkinan Anda akan melaporkan kasus tersebut kepada PIHAK INTERNAL di Perguruan Tinggi ABC (missalnya atasan Anda atau pihak manajemen yang lebih tinggi) DENGAN memberitahukan identitas Anda?

(4) Bagaimanakah tingkat kemungkinan Anda akan melaporkan kasus tersebut kepada PIHAK EKSTERNAL di luar Perguruan Tinggi ABC (missalnya penegak hukum) DENGAN memberitahukan identitas Anda?

\section{Kasus 2}

Andi adalah rekan kerja Dedi yang lebih senior di Divisi Keuangan Perguruan Tinggi ABC. Keduanya sedang menyiapkan dokumen pertanggungjawaban keuangan (SPJ) untuk sebuah proyek pelatihan. Dedi mengetahui bahwa kebutuhan dokumen laporan keuangan seperti faktur dan kuitansi pembelian harus lengkap dengan stempel asli dan tanda tangan pada bukti transaksi. Sayangnya dokumen untuk pembelian konsumsi senilai Rp 500 ribu tidak lengkap. Andi mengatakan bahwa ia sudah menyiapkan faktur dan kuitansi kosong. Andi menuliskan nominal $\mathrm{Rp} 1$ juta pada faktur dan kuitansi kosong tesebut lengkap dengan stempel dan tanda tangan palsu. Dengan demikian, Andi memperoleh kelebihan senilai $\mathrm{Rp} 500$ ribu yang diambil untuk dirinya. Karena hanya Dedi yang mengetahui tindakan tersebut, maka jika Dedi melaporkan, Andi mengetahui siapa yang melaporkan. Hal ini akan memperburuk hubungan kerja Dedi dengan Andi. Seandainya Anda adalah Dedi.

(1) Bagaimana tingkat kemungkinan Anda akan melaporkan kasus tersebut kepada PIHAK INTERNAL di Perguruan Tinggi ABC (missalnya atasan Anda atau pihak manajemen yang lebih tinggi) TANPA memberitahukan identitas Anda?

(2) Bagaimana tingkat kemungkinan Anda akan melaporkan kasus tersebut kepada PIHAK EKSTERNAL di luar Perguruan Tinggi ABC (misalnya penegak hukum) TANPA memberitahukan identitas Anda?

(3) Bagaimanakah tingkat kemungkinan Anda akan melaporkan kasus tersebut kepada PIHAK INTERNAL di Perguruan Tinggi ABC (missalnya atasan Anda atau pihak manajemen yang lebih tinggi) DENGAN memberitahukan identitas Anda?

(4) Bagaimanakah tingkat kemungkinan Anda akan melaporkan kasus tersebut kepada PIHAK EKSTERNAL di luar Perguruan Tinggi ABC (misalnya penegak hukum) DENGAN memberitahukan identitas Anda?

\section{Item Pertanyaan Variabel Sikap}

(1) Setujukah Anda terhadap manfaat pelaporan korupsi yang Anda lakukan di bawah ini?

a) Melindungi organisasi dari dampak negatif yang lebih besar akibat perilaku korupsi

b) Membantu memberantas korupsi

c) Melindungi kepentingan umum

d) Menjalankan kewajiban sebagai karyawan

e) Menegakkan kewajiban etis dan keyakinan moral

(2) Seberapa pentingkah hasil berikut jika Anda melaporkan korupsi?

a) Melindungi organisasi dari dampak negatif yang lebih besar akibat perilaku korupsi

b) Membantu memberantas korupsi

c) Melindungi kepentingan umum

d) Menjalankan kewajiban sebagai karyawan

e) Menegakkan kewajiban etis dan keyakinan moral 


\section{Item Pertanyaan Variabel Persepsi Kontrol Perilaku}

(1) Jika Anda melaporkan korupsi di, setujukah Anda dengan pernyataan berikut ini?

a) Organisasi akan mengabaikan laporan saya

b) Saya akan menghadapi banyak kesulitan dalam proses pelaporan

c) Laporan adanya korupsi tidak akan membuat perbedaan apapun di organisasi ini

d) Pelaku korupsi akan melakukan balas dendam kepada saya

e) Saya akan memperoleh pandangan negatif dari rekan kerja

(2) Seberapa besar pengaruh isu-isu di bawah ini terhadap niat Anda untuk melaporkan korupsi?

a) Pengabaian laporan korupsi oleh organisasi

b) Kesulitan dalam proses pelaporan

c) Laporan korupsi tidak berpengaruh bagi organisasi

d) Balas dendam oleh pelaku korupsi

e) Pandangan negatif dari rekan kerja

\section{Item Pertanyaan Variabel Persepsi Dukungan Organisasi}

(1) Organisasi ini peduli terhadap kepuasan kerja Saya ditempat kerja

(2) Organisasi ini tidak peduli terhadap pendapat yang Saya utarakan*

(3) Organisasi ini akan memberikan bantuan jika Saya memerlukan bantuan dalam kasus tertentu yang penting

(4) Pertolongan tidak selalu tersedia dari organisasi ini ketika saya menghadapi masalah dalam pekerjaan*

(5) Organisasi ini secara maksimal mempertimbangkan tujuan karyawan dan nilai karyawan

\section{DAFTAR PUSTAKA}

Adebayo, D. O. 2005. Ethical attitudes and prosocial behaviour in the Nigeria police: moderator effects of perceived organizational support and public recognition. Policing: An International. Journal of Police Strategies and Management, 28 (4), 684-705.

Ahern, K. M. dan S. McDonald. 2002. The Beliefs of Nurses Who Were Involved in A Whistleblowing Event, Journal of Advanced Nursing, 38 (3), 303-309.

Ajzen, I. 1991. The theory of planned behaviour. Organizational Behaviour and Human Decision Processes, 50 (2), 179-211.
Alleyne, P., M. Hudaib, dan R. Pike. 2013. Towards a Conceptual Model of Whislte-blowing Intention Among External Auditors. The British Accounting Review, 45: 10-23.

Brennan, N. Dan J. Kelly. 2007. A study of whistleblowing among trainee auditors. British Accounting Review, 39 (1), 61-87.

Callahan, E.S. dan T. M. Dworkin. 2000. The state of state whistleblower protection, American Business Law Journal, 38 (1), 99-175.

Cropanzano, R. dan M. S. Mitchell. 2005. Social Exchange Theory: An Interdisciplinary Review. Joumal of Management, 31, 874-900.

Eisenberger, R., R. Huntington, S. Hutchinson, dan D. Sowa. 1986. Perceived organizational support. Journal of Applied Psychology, $71(3), 500-507$.

Elias, R. Z. 2008. Auditing Students' Professinal Commitment and Anticipatory Socialization and Their Relationship to Whistleblowing. The Managerial Auditing Journal, 23 (3), 283294.

Elliston, F. A. 1982. Anonymity and Whistleblowing. Journal of Business Ethics. 1 (3), 167-177.

Evanauli, R. P., dan I. Nazaruddin. 2013. Penerimaan Auditor atas Dysfunctional Audit Behavior: Sebuah Pendekatan Karakteristik Personal Auditor. Jurnal Akuntansi dan Investasi, 14(2), 158-167.

Gorta, A. dan S. Forell. 1995. Lavers of Decision: Linking Social Definitions of Corruption and Willingness to Take Action, Crime, Law \& Social Change, 23, 315-343.

Gouldner, A. W. 1960. The norm of reciprocity: a preliminary statement. American Sociological Review, 25 (2).

Hair, J. R., F. Joseph, W. C. Black, B. J. Babin, dan R. E. Anderson. 2010. Multivariate Data Analysis, Seventh Edition. Pearson Prentice Hall.

Hartono, J. dan W. Abdillah. 2008. Pedoman Survei Kuesioner: Mengembangkan Kuesioner, Mengatasi Bias dan Meningkatkan Respon. Yogyakarta: BPFE UGM.

Hooks, K. L., S. E. Kaplan dan J. J. Schultz Jnr. 1994. Enhancing communication to assist in fraud prevention and detection. Auditing: $A$ Journal of Practice \& Theory, 13 (2), 86-117.

Kaplan, S. E. 2012. An Examination of Anonymous and Non-Anonymous Fraud Reporting Channels. Advances in accounting, 28 (1), 8895.

Kaplan, S. E. dan S. M. Whitecotton. 2001. An examination of the auditors' reporting 
intentions when another auditor is offered client employment. Auditing: A Journal of Practice and Theory, 20 (1), 45-63.

Mesmer-Magnus, J. R. dan C. Viswesvaran. 2005. Whistleblowing in Organizations: An Examination of Correlates of Whistleblowing Intentions, Actions, and Retaliation, Journal of Business Ethics, 62 (3), 277-297.

Miceli, M. P. dan J. P. Near. 1985. Characteristics of Organizational Climate and Perceived Wrongdoing Associated with Whisde-Blowing Decisions, Personnel Psychology, 38, 525544.

Miceli, M. P. dan J. P. Near. 1992. Situation variables affecting the whistle-blowing decision: a review of the literature. Advances In Management Accounting, 1, 109-139.

Park, H. dan J. Blenkinsopp. 2009. Whistle-blowing as planned behavior - a survey of South Korean police officers. Journal of Business Ethics, 85(4), 545-556.

Patel, C. 2003. Some Cross-cultural Ovidence on Whistle-blowing as an Internal Control Mechanism. Journal of International Accounting Research, 2, 69-96.

Putri, C. M. 2016. Pengaruh Jalur Pelaporan dan Tingkat Religiusitas terhadap Niat Seseorang Melakukan Whistleblowing. Jurnal Akuntansi dan Investasi, 17 (1), 42-52.

Rothschild, J. dan D. Miethe. 1999. Whistle-Blower Disclosures and Management Retaliation. Work and Occupations. 26, 107-128.

Sofyani, H., dan R. Akbar. 2013. Hubungan Faktor Internal Institusi dan Implementasi Sistem Akuntabilitas Kinerja Instansi Pemerintah (SAKIP) di Pemerintah Daerah. Jurnal Akuntansi dan Keuangan Indonesia, 10 (2), 184-205.

Sofyani, H. dan R. Akbar. 2015. Hubungan Karakteristik Pegawai Pemerintah Daerah dan Implementasi Sistem Pengukuran Kinerja: Perspektif Ismorfisma Institusional. Jurnal Akuntansi \& Auditing Indonesia, 19 (2), 153173.

Sugiyono. 2013. Metode Penelitian Bisnis (Pendekatan Kuantitatif, Kualitatif, dan R\&D). Bandung: Alfabeta.

Trongmateerut, P. dan J. T. Sweeney. 2013. The Influence of Subjective Norms on WhistleBlowing: A Cross-Cultural Investigation. Journal of Business Ethics, 112 (3), 437-451.

Undang-Undang Republik Indonesia Nomor 13 tahun 2006 tentang Perlindungan Saksi dan Korban.
Wayne, S. J., L. M. Shore dan R. C. Liden. 1997. Perceived organizational support and leadermember exchange: a social exchange perspective. Academy of Management Journal, 40 (1), 82-111.

Winardi, R. D. 2013. The Influence of Individual and Situational Factors on Lower-Level Civil Servants' Whistle-Blowing Intention in Indonesia. Journal of Indonesian Economy and Business. 28 (3); 361-376. 